\title{
Earthworm avoidance behavior to antimicrobial sulfadiazine on tropical artificial soil
}

\author{
Candello, F.P.*; Guimarães, J.R.; Nour, E.A.A. \\ UNICAMP, Sanitation Laboratoy, School of Civil Engineering, Architecture and Urban Desing, University of Campinas, \\ Campinas, São Paulo, Brazil.
}

Received September 29, 2017; Accept May 21, 2018

\begin{abstract}
Veterinary pharmaceuticals can reach the soil via animal excretions and cause impacts on aquatic and terrestrial ecosystems. In this work, we employed a standardized avoidance behavior test to assess the sublethal effects of antimicrobial sulfadiazine on the earthworm Eisenia andrei. Cultivation of red worms was based on an alternative substrate made of mostly household vegetable wastes and dry leaves. The bioassays were performed with tropical artificial soil spiked with the tests substance at five different concentrations ranging from 0.01 to $100 \mathrm{mg}$ sulfadiazine $\mathrm{kg}^{-1}$. The outcome resulted in avoidance response of $30 \%$ (maximum) and a nonlinear concentration-response curve, differing from classical pollutant responses and correlating with those asymmetric responses over the environment caused by some rare xenobiotics. Avoidance tests were validated with reference substance, resulting in an EC50-48h of $819 \mathrm{mg}$ boric acid $\mathrm{kg}^{-1}$ (628-1066 mg boric acid kg-1 95\% confidence interval). We concluded that the avoidance test with $E$. andrei is useful as a standardized tool for a rapid ecotoxicological screening of soil.
\end{abstract}

Keywords: avoidance test, Eisenia andrei, pharmaceuticals, sulfonamides, terrestrial ecotoxicology.

\section{INTRODUCTION}

The repellency of some chemicals over terrestrial fauna has been known and assessed for years on several animal taxa, as Annelida, Collembola, Isopoda, Acari, among others (Eijsackers, 1978; Hund-Rinke et al., 2003; Aldaya et al., 2006; Van Gestel, 2012), usually employing their chemical sensors and signals to avoid deleterious food or habitat.

Soil acceptance for microbial life is usually affected, among others, by widespread of veterinary pharmaceuticals (Thiele-Bruhn, 2003; Sarmah et al., 2006; Schmitt; Römbke, 2009), such as antibiotics intended to treat and prevent diseases, increasing animal production and profit. Belonging to this therapeutic class, synthetic drugs as sulfonamides (SAs) have been widely used for animal health (less used in human medicine), since before penicillin discovery. After tetracyclines, SAs are the most used antibiotics in European Union and highly employed in aquaculture and intensive livestock farming (Thiele-Bruhn, 2003; García-Galan et al., 2009).
Most of the antibiotics, though, are partially absorbed in the organism body, with 30 to $90 \%$ of administered original pharmaceuticals or their metabolites being excreted by animal metabolism (Rang \& Dale, 1991). They pose a real risk in the case of reaching the environment, because they may keep their bioactive potential, leading to harmful effects on terrestrial and aquatic ecosystems, and also by triggering bacterial resistance.

Sulfadiazine (SDZ), one of the most employed SAs in pig's livestock, shows intermediate active duration (10-12 h) and relatively rapid absorption and excretion. This fact implies in a short withdrawal period ( $\sim 5 \mathrm{~d})$ (Marques, 2012), one of the reasons we took SDZ as a model for researching the environmental insecurity involving the use of veterinary medicines in the soil.

Ecotoxicological bioassays are suitable to get information about the effects of pollutants in soil and proposed to complement conventional chemical analysis. Whereas aquatic test with soil eluates are employed to get information on the contaminant's fraction which can reach the groundwater,

*Corresponding author: Fernando Pena Candello; e-mail: fpenacan@g.unicamp.br 
essaying the soil retention function (Hund-Rinke, Wiechering, 2001), in terrestrial systems, the focus is assessing the habitat function, i.e., the ability of soil or soil material to host soil organisms, assuring their natural interactions. Sublethal tests, such as the avoidance test, also evaluate the influence of contaminants and chemically spiked soil over the earthworm's behavior (ISO, 2008).

The habitat function may be injured by the presence of pollutants as pharmaceuticals, found in distinct soil fractions and bioavailability levels, depending on soil physical and chemical features, as well as their chemical speciation (Sarmah et al., 2006).

Escape or avoidance tests are rapid screening methods with high sensitivity, relative easy performance, for evaluating sublethal stress - a parameter not checked by traditional acute or chronic tests (Yeardley et al., 1996; ISO, 2008).

Attraction and repulsion are both features which increase the ecological fitness of animal sensitive species (Aldaya et al., 2006). Van Gestel (2012) states that the avoidance response may be an endpoint as sensitive as reproduction for some chemicals, while it may be as sensitive as survival for other substances.

The behavioral response is fundamentally an effect at the organism level, which can be defined as the action, reaction or activation of a given system, under a set of specific conditions representing the integration of the biochemical and physiological processes. In addition, the behavior as an endpoint in ecotoxicology is gaining increasing recognition because its sensitivity is considered, in some cases, ten to one thousand times greater than the conventional median lethal concentration, the LC50 (HELLOU et al., 2008; HELLOU, 2011; ROBINSON, 2009).

When exposed to certain contaminants, organisms may display certain potential behavioral responses, such as: avoidance (habitat escape); altered sense of direction or balance; abnormal substrate excavation; phobias; altered feeding, walking, and breathing, among others. Avoidance behavior is usually the first signal readily demonstrated by the organism as a defense mechanism before succumbing to other effects less immediate of the adverse conditions exposure (HELLOU, 2011). The observation of these behavioral responses in controlled assays may be useful for the assessment of environmental risk to soils known or suspected of contamination, and for the determination of chemicals toxicity, as a complement to conventional physical and chemical analysis.

The lack of information about the behavior and fate of antibiotics residues in soil, considered emerging concerns in environmental science, prevent doing a precise correlation between the potential of exposure and possible damages to the environment and, in extent, to human health.

Previous studies have not correlated worms' avoidance behavior and SAs concentration in soils, although many other chemicals have already been tested (Stephenson et al., 1998; Schaefer, 2001; Hund-Rinke; Wiechering, 2001; Reinecke et al., 2002; Schaefer, 2003). Even though, we considered necessary and decided to verify the sulfadiazine effect considering the different climate conditions in tropical regions.

This work aimed to assess the effect of SDZ on the avoidance behavior of the oligochaete Eisenia andrei (Californian red earthworm), a typical annelid of the soil biocenosis, in an attempting to determine its sublethal concentration in tropical artificial soil, according to protocol 17512-1 (ISO, 2008).

\section{MATERIAL AND METHODS}

\section{Test organism}

A batch of earthworm Eisenia andrei (Oligochaeta: Lumbricidae) was obtained from Minhobox ${ }^{\mathrm{TM}}$, a company in Juiz de Fora, MG, Brazil, three months before the beginning of the experiments. They were cultured in the Sanitation Laboratory at the School of Civil Engineering, Architecture, and Urban Design, University of Campinas (Labsan/FEC/ Unicamp), Campinas, SP, Brazil. The organisms were kept and fed in 15-L plastic containers, with a household made substrate and composted cow manure substrate, more detailed further. Prior to tests $(24 \mathrm{~h})$, earthworms were randomly taken from the substrate and kept in $4 \mathrm{~L}$ plastic trays filled with soil test (TAS). Only clitellate (sexually mature) adults with individual biomass of 0.3 to $0.6 \mathrm{~g}$ were selected, based on the requirements for using this species in the avoidance tests (Garcia et al., 2004 and ISO, 2008).

\section{Culture Substrate}

The substrate used to keep and feed the earthworms was prepared from household vegetable wastes (skins, seeds, and stalks) of fruits, vegetables, and herbs, mixed with crushed tree leaves and twigs. The mixture was held in a hard plastic container, 15-L capacity, with perforated bottom and set above another equal dimension whole bottom container. Once a week, $4 \mathrm{~L}$ of household vegetable waste and $4 \mathrm{~L}$ of shredded dried leaves and twigs were added to the top container for one month.

The upper container had its bottom (base) drilled in 80 holes (5 $\mathrm{mm}$ diameter), equally distributed to allow liquid drainage resulted from compost degradation. To keep the necessary moisture for the pre-composting process, potable water $(500 \mathrm{~mL})$ was supplied twice a week and mixed. After the first month, considered container filling period, the material addition was ceased, and only water supply was held and the substrate revolved for one month further, in order to prepare the substrate to supply the organisms. Periodically, the bottom container was manually drained to remove liquid from the degradation of the compounds of the upper case. The overlapping containers system was kept at room temperature (21 to $29^{\circ} \mathrm{C}$ ) and natural lighting. The upper was covered by 
a thin porous cloth to prevent insects and vectors approaches while allowing natural aeration.

After two months of preparation, the substrate was ready for animal supply. Earthworms were kept in this medium while another set of containers had its substrate in preparation. After two cycles of substrate consumption (about 20 days each) organisms were fed in a more nitrogen-rich substrate, consisting of composted cow manure (naturally raised cows) for one month prior to the tests. This substrate was purchased in 50-L bags, from the same earthworm matrices supplier.

\section{Test soil}

The test soil used was the tropical artificial soil (TAS), according to the formulation of OECD artificial soil (OECD, 1984), modified by Garcia (2004), who replaced the traditional sphagnum peat by powdered coconut fiber as the organic matter portion (Nunes; Espíndola, 2012).

TAS was prepared to assemble (in dry mass): $70 \%$ fine sand, $20 \%$ kaolinite clay and $10 \%$ powdered coconut fiber. Its $\mathrm{pH}$ value was adjusted to $6.0 \pm 0.5$ with calcium carbonate before the moisture adjust, which was set up to $60 \%$ of the TAS maximum water holding capacity (WHC).

Fine sand (particle size $0.1 \mathrm{~mm}$ ) was obtained from the Institute for Technological Research (IPT) of the State of São Paulo, Brazil, which was washed to remove organic material, drying in a rotary kiln $\left(\sim 250^{\circ} \mathrm{C}\right)$ and sieving.

White clay (kaolin powder 26 U.S.P.) was purchased from Synth and coconut fiber (Golden Mix T-granulate 80, agricultural substrate) was acquired from Amafibra company.

Before TAS preparation, coconut fiber portions were sieved through a $2.0 \mathrm{~mm}$ mesh, kept in plastic trays and naturally dried for a week, with daily mixing up to ensure the material is visibly dry before adding sand and clay to form TAS.

After mixing all the dry materials, the soil was distributed in $1 \mathrm{~kg}$ portions (plastic trays) prior to addition of water (control) or test solution (exposure concentrations). The TAS physical and chemical parameters met up the recommended conditions (ISO, 2008) and the measured pH (ISO, 1994), moisture and WHC (Monteiro and Frighetto, 2000) are presented in Table 1.

\section{Sulfadiazine and its concentration levels}

The antimicrobial sulfadiazine (SDZ) was purchased from Sigma-Aldrich, Belgium.

Table 1 Chemical and physical parameters of the tropical artificial soil (TAS) prepared for using in avoidance tests.

\begin{tabular}{|c|c|c|c|c|}
\hline \multicolumn{2}{|c|}{$\mathrm{pH}^{\mathrm{a}}$} & \multirow[b]{2}{*}{$\mathrm{WHC}_{\max }(\%)$} & \multirow{2}{*}{$\begin{array}{l}\text { Moisture }(\%) \\
\text { (before water addition) }\end{array}$} & \multirow{2}{*}{$\begin{array}{r}\text { Moisture (\%) } \\
\text { (after water addition) }\end{array}$} \\
\hline $\begin{array}{c}\mathrm{CaCl}_{2} \\
0.01 \mathrm{~mol} \mathrm{~L}^{-1}\end{array}$ & $\mathrm{H}_{2} \mathrm{O}$ & & & \\
\hline $5.8 \pm 0,1$ & $6.6 \pm 0,2$ & 77.5 & 0.3 & 51.0 \\
\hline
\end{tabular}

The day before the test, a standard stock solution (250

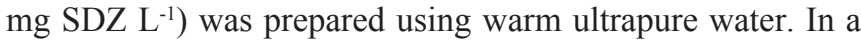
glass beaker, $0.5 \mathrm{~L}$ of water containing the test substance was heated at $60^{\circ} \mathrm{C}$ on a hot plate with constant magnetic stirring on a fume hood.

Test solutions for the avoidance test were prepared from the dilution of the stock standard solution ( $\left.250 \mathrm{mg} \mathrm{SDZ} \mathrm{L}^{-1}\right)$. The stock solution itself was also used as the most concentrated test solution. Therefore, these nominal concentrations were: $0.025,0.25,2.5,25$ and $250 \mathrm{mg}_{\mathrm{SDZ}} \mathrm{L}^{-1}$. Final concentrations of SDZ on soil, resulting from the addition of these solutions, are presented in the next section of this paper.

The concentration range employed in the tests was not based on previous studies, since we could not find published outcomes regarding earthworm avoidance test and sulfonamides, or earthworms and sulfadiazine toxicity tests (endpoint: lethality, reproduction), for the best of our knowledge.

Some physical-chemical properties of sulfadiazine, as its molecular weight and most reported pK values can be seen in Table 2.

\section{Experimental procedure}

In the earthworm avoidance tests, $400 \mathrm{~mL}$ of sulfadiazine aqueous solutions (5 concentrations) were manually incorporated into TAS ( 5 plastic trays containing $1 \mathrm{~kg}$ of dry TAS each). The material was upturned, resulting in nominal concentrations of $0.01,0.1,1,10$ and $100 \mathrm{mg}$ SDZ kg-1 (dry mass) (Garcia, 2004; Nunes; Espíndola, 2012). On the control, it was only added ultrapure water. The amounts of the incorporated solutions into SAT were calculated to adjust the humidity to $60 \%$ of the maximum water holding capacity (WHC), previously determined.

The tests took place as soon as all the solutions were spiked into the artificial soil portions. Every effect concentration is reported in this paper as nominal value, as typically used in soil ecotoxicology, i.e. no residues assays were performed, according to technical guidelines (ISO, 2008).

Aiming to refine the range of test concentrations, a previous range-finder test was carried out with the concentrations of 0.01, 0.1 and $1 \mathrm{mg} \mathrm{SDZ} \mathrm{kg}^{-1}$ (dry mass).

Avoidance tests were performed during 48 hours under a photoperiod of $12 \mathrm{~h}$ light $/ 12 \mathrm{~h}$ dark, according to standard ISO 17512-1 (2008), adapted to tropical conditions: exposure temperature of $25^{\circ} \mathrm{C}$ and coconut fiber compounding the TAS instead of sphagnum peat (Garcia, 2004; Nunes; Espíndola,

Table 2 Chemical-physical properties of sulfadiazine.

\begin{tabular}{ccccccc}
\hline $\begin{array}{c}\text { MW } \\
\left(\mathrm{g} \mathrm{mol}^{-1}\right)\end{array}$ & $\begin{array}{c}\text { Solubility } \\
\left(\mathrm{mg} \mathrm{L}^{-1}\right)\end{array}$ & $\mathrm{pK}_{\mathrm{a}}$ & $\mathrm{pK}_{\mathrm{b}}$ & $\mathrm{VP}(\mathrm{mmHg})$ & $\mathrm{K}_{\mathrm{ow}}$ & $\begin{array}{c}\text { Henry's constant } \\
\left(\mathrm{atm} \mathrm{m}^{3} \mathrm{~mol}^{-1}\right)\end{array}$ \\
\hline 250.3 & $77\left(25^{\circ} \mathrm{C}\right)$ & 6.4 & 1.6 & $4.3110^{-8}$ & 0.813 & $1.6010^{-10}$ \\
\hline
\end{tabular}

MW: molecular weight; $\mathrm{pK}_{\mathrm{a}}$ : acidity constant; $\mathrm{pK}_{\mathrm{b}}$ basicity constant; VP: vapor pressure; $\mathrm{K}_{\mathrm{ow}}$ : octanol-water partition coefficient (CAS, 2013; Thiele-Bruhn et al., 2003). 
2012). Four avoidance tests were carried out employing five different concentrations of antimicrobial sulfadiazine as the test chemical, in four replicates per concentration, consisted of transparent polypropylene vessels of circular base (basal diameter: $12 \mathrm{~cm}$, height: $9 \mathrm{~cm}$, capacity: 1L). Their outside was wrapped around with aluminum foil to prevent light interference, except the lids, where small holes were made to promote aeration. The vessel inside volume was half split by a removable plastic divider before the introduction of 350 $\mathrm{g}$ of prepared treatment and control soils, respectively, in the left (section A) and right (section B) sides of the vessel, comprising a total soil content of $700 \mathrm{~g}$ per replica. Next, the divider was pulled up and ten earthworms, previously acclimated in control soil, were placed on the separating line between the two-faced soils. Earthworms were randomly selected from acclimatization tray and added straight to the test vessels, with no previous treatment.

After the exposure period, the plastic divider was reintroduced into the vessels, separating soil control and treatment. The count was carried out, and the number of organisms in each section was observed and registered, as well as the number of dead or lost earthworms, if appropriate, once the test is considered invalid if this value exceeds $10 \%$ in each assessed concentration.

The dual control test was performed in parallel (and once apart) where the four replicates contained soil control in both halves (sections) of the vessel test. This test checks the fulfillment of another avoidance test validation criteria: homogeneous distribution of organisms in vessels test in the absence of contaminants (ISO, 2008).

Four sensitivity tests were performed similar to that used for TAS with SDZ, but instead, the test chemical was the reference toxicant boric acid $\left(\mathrm{H}_{3} \mathrm{BO}_{3}\right.$, PA 99.5 to $100.5 \%$, Nuclear) and test solutions were added to the artificial soil to aim the nominal concentrations of $125,250,500,750$ and $1500 \mathrm{mg} \mathrm{H}_{3} \mathrm{BO}_{3} \mathrm{~kg}^{-1}$.

\section{Data analysis}

The responses of soil assays containing either sulfadiazine as boric acid were calculated as the avoidance percentage per concentration according to the equation 1 (ISO, 2008):

Avoidance $(\%)=\left[\left(n_{c}-n_{t}\right) / N\right] \times 100 \quad$ (equation 1)

Where: $n_{c}=$ number of earthworms found in section $B$ (control soil), $\mathrm{n}_{\mathrm{t}}=$ number of earthworms found in Section A (test soil), $\mathrm{N}=$ total number of earthworms (sum of replicates per concentration).

Negative responses (i.e., organisms prefer the test soil) were considered as $0 \%$ avoidance and the soil is considered toxic if more than $80 \%$ of exposed organisms prefer the control soil (avoidance $>60 \%$ ) (ISO, 2008), better explained in the following paragraphs.

Intermediate results represent different levels of toxicity and depend on the number of earthworms found in soil control (section B of the recipients test or chambers).
Due to equation 1, from 40 organisms exposed, at the end of the test: if 20 organisms are found in section A (test soil) and 20 organisms in section B (control soil): avoidance $=0 \%$; if 16 are found in section A and 24 in section B: avoidance $=20 \%$; if 12 are found in section $\mathrm{A}$ and 28 in section $\mathrm{B}$ : avoidance $=40 \%$; if 8 are found in section $\mathrm{A}$ and 32 in section B: avoidance $=60 \%$ (32 earthworms represent $80 \%$ of the total exposed organisms).

The Fisher exact test was chosen to analyze the significance of the response, using the one-tailed test with a null hypothesis that, in the absence of adverse effects, at least $50 \%$ of the organisms are assumed to be found in soil test section, as a requirement for this statistical test to be used. The null hypothesis was rejected for a probability equal or lower than 0.05. (Natal-da-Luz; Römbke; Sousa, 2008).

For the dual control test was considered the mean number of organisms $( \pm \mathrm{SD})$ found in each section of the test vessel. To validate the test, the outcome must present a homogeneous earthworm distribution (40 to $60 \%$ ratio) in each section.

Statistical analyses were performed using the software BioEstat 5.4. Trimmed Spearman-Karber method was used to calculate median effective concentration (EC50-48h) whenever possible from tests data (ISO, 2008).

\section{RESULTS}

\section{Avoidance test validation}

The avoidance test is considered invalid if dead or missing organisms were greater than $10 \%$ per treatment (ISO, 2008), once it is intended to assess sublethal concentrations. Moreover, for the dual control test, equal distribution of earthworms must be reached, with a 40 to $60 \%$ presence ratio on each side of test vessel containing control soil, since all the vessels are in the same orientation in the incubation chamber.

No mortality or missing organisms were observed during the tests, so avoidance test validation criteria have been met. For the dual control test, organisms were homogeneously distributed in both sections of the test vessels, with an average presence ratio of $48 \%$ in section A and 52\% in section B (Figure 1).

\section{Reference Toxicant Test}

Boric acid is the reference toxicant chemical for evaluating the performance and reproducibility of the avoidance test (ISO, 2008). The boric acid concentrations of 750 and $1500 \mathrm{mg} \mathrm{H}_{3} \mathrm{BO}_{3} \mathrm{~kg}^{-1}$ in TAS caused significant avoidance responses, according to Fisher Exact Test. While the lowest concentrations tested $\left(125,250\right.$ and $\left.500 \mathrm{mg}_{\text {нзвоз }} \mathrm{kg}^{-1}\right)$ did not present significant responses, since the values are close to the expected distribution range of organisms in the absence of adverse effects (Figure 2).

The concentration of $125 \mathrm{mg} \mathrm{H}_{3} \mathrm{BO}_{3} \mathrm{~kg}^{-1}$ caused organisms attraction (23\%), although ISO protocol states considering $0 \%$ 
avoidance whenever there were among 0 to $80 \%$ of preference for soil test over soil control.

The median effective concentration (EC50-48h) was $819\left(628\right.$ - 1066) mg. $\mathrm{kg}^{-1} \mathrm{H}_{3} \mathrm{BO}_{3}$, according to the statistical method (ISO, 2008).

\section{Sulfadiazine Effects}

The SDZ earthworm avoidance test on TAS resulted in mean responses lower than $30 \%$, even at SDZ concentrations higher than those normally reported for the environment (Figure 3).

The results aiming at establishing a range of test organism (E. andrei) escape behavior for the substance studied show responses not associated with the traditional concentrationresponse curve.

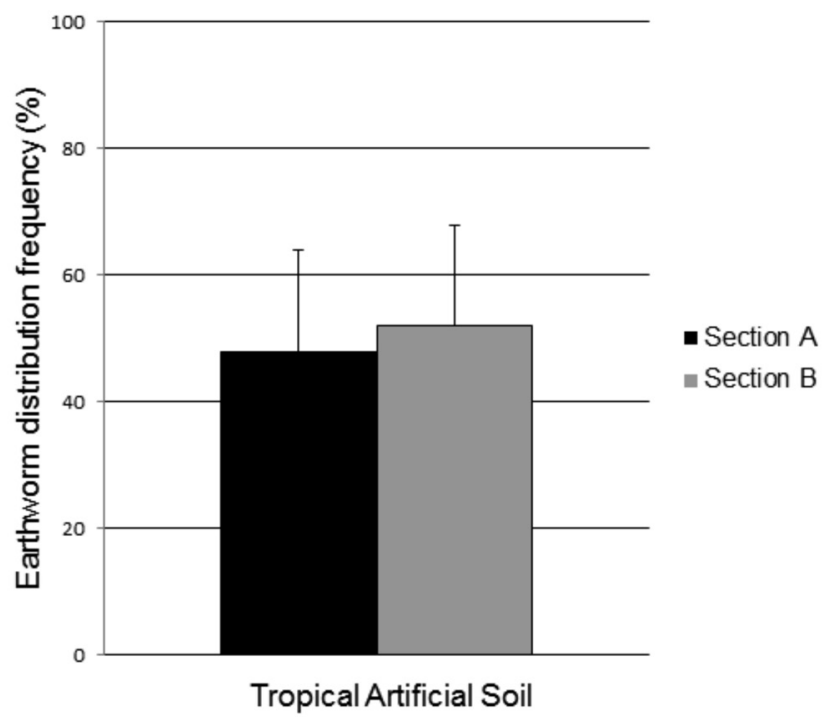

Figure 1 Dual control test: percentage of organisms (mean $\pm S D, n=20$ ) in each section of the test vessels. There was no statistically significant difference in the distribution of organisms in the Fisher Exact Test ( $\mathrm{p} \geq 0.05)$.

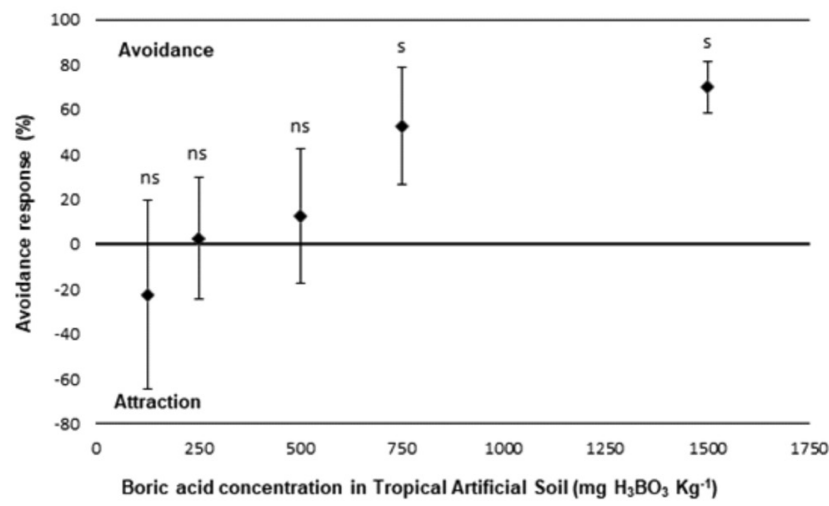

Figure 2 Reference toxicant test: percentage of $E$. andrei avoidance response (mean $\pm \mathrm{SD}, \mathrm{n}=16$ ) in TAS with different acid boric concentrations. Bars represent standard deviation. $(\mathrm{ns})=$ not significant response $(\mathrm{p} \geq 0,05) ;(\mathrm{s})=$ significant response $(\mathrm{p}<0,05)$, according to Fisher Exact Test.

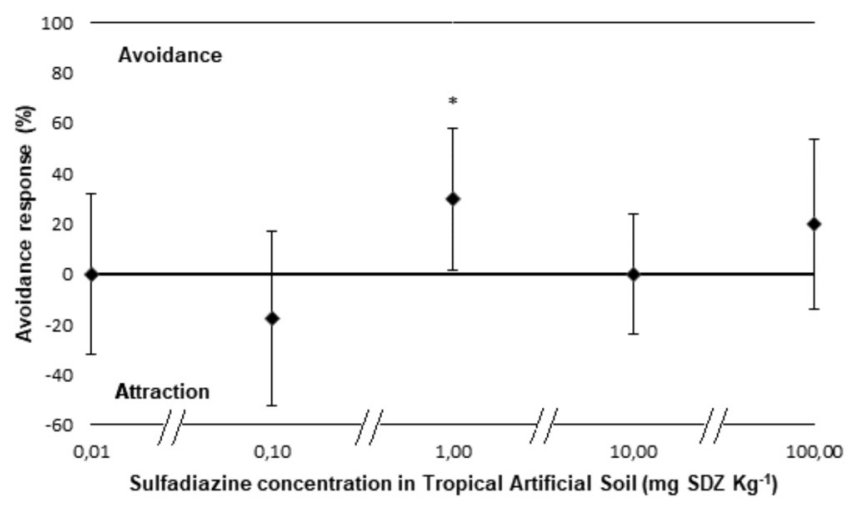

Figure 3 Avoidance test with sulfadiazine: percentage of $E$. andrei avoidance response (mean $\pm \mathrm{SD}, \mathrm{n}=16$ ) in TAS with different sulfadiazine concentrations. Bars represent standard deviation. $* 1 \mathrm{mg} \mathrm{SDZ} \mathrm{kg}^{-1}$ : single significant response $(\mathrm{p}<0,05)$, according to Fisher Exact Test.

\section{DISCUSSION}

Since the solubility of sulfadiazine is low $\left(77 \mathrm{mg} \mathrm{L}^{-1}\right.$ at $20^{\circ} \mathrm{C}$ ) and also depends on how it has been crystallized, during its solubilization it was preferred to adopt a higher temperature $\left(60^{\circ} \mathrm{C}\right)$ and constant stirring - we highlight that such conditions do not degrade the SDZ molecule.

Aiming the fulfillment of tropical conditions, the exposure temperature was modified from $20^{\circ} \mathrm{C}$ to $25^{\circ} \mathrm{C}$. The Same adaptation was employed by Garcia et al. (2008) and, Nunes and Espíndola (2012), in an artificial soil test with the same composition as used in the present study, at $28 \pm 2^{\circ} \mathrm{C}$ and $25 \pm 2^{\circ} \mathrm{C}$ respectively, with no issues related to the method validation.

Despite the recommendation found in some studies, test organisms were not washed and dried on tissue paper before use in the essays, to avoid coelomic fluid release through the epithelium and possible stress of the organisms, observed in previous manipulation care activities.

In the sensitivity tests, it was observed a weak (not significant) earthworm attraction at $125 \mathrm{mg} \mathrm{H}_{3} \mathrm{BO}_{3} \mathrm{~kg}^{-1}$ concentration: nevertheless, it was decided to keep the negative value of the avoidance response (attraction) on the figure.

In fact, the sensitivity tests indicated that organisms responded, according to a dose-response curve, to the repellent effect of the reference substance boric acid.

In the study developed by Princz and Scroggins (2003), several comparative tests were carried out on reference soil (Alberta black chernozem). A two-section test vessel was used, EC50-48h for Eisenia andrei avoidance response to boric acid was $794 \mathrm{mg} \mathrm{H}_{3} \mathrm{BO}_{3} \mathrm{~kg}^{-1}$ (confidence limits: 537 to $\left.1202 \mathrm{mg} \mathrm{H}_{3} \mathrm{BO}_{3} \mathrm{~kg}^{-1}\right)$, similar to the obtained value in this study ( $819 \mathrm{mg} \mathrm{H}_{3} \mathrm{BO}_{3} \mathrm{~kg}^{-1}$ ), thus meeting the protocol validity criteria (ISO, 2008). 
Although preliminary essays (unpublished data) with the test substance (SDZ) had signed avoidance behavior of the earthworms from $1.0 \mathrm{mg} \mathrm{SDZ} \mathrm{kg}^{-1}$ concentration, in definitive essays with higher concentrations, however, this behavior was not observed.

Selection of the test concentration levels was based on the maximum amount of sulfonamide residues related to being detected in agricultural soils: up to $0,011 \mathrm{mg} \mathrm{kg}^{-1}$ (Höper et al., 2002 apud Thiele- Bruhn, 2003), since no previous data could be found regarding sulfadiazine and earthworm avoidance behavior.

Probably higher SDZ concentrations would be necessary to show a clearer response and provide information on this subject. Although, a brief discussion upon linearity of response should be made as follows: a concentration or doseresponse curve is the quantitative relationship between the experimental concentration and the adverse effects. In fact, for most chemicals, this ratio is sigmoidal, such that the effects increase abruptly above a certain threshold concentration, according to Clotfelter et al. (2004).

Such approach seems to fit well when the toxicity of the substance is evident, and there is a simple monotonic relationship between dose and response. However, several emerging pollutants and endocrine disrupters (as a wide range of herbicides, pesticides and pharmaceutical agents, and metals as cadmium and mercury) differ from the classical pollutants in this relationship (Calabrese; Baldwin, 2003).

Alworth et al. (2002) state that unusual concentrationresponse relationships may occur with some xenobiotics. We have the "U-shaped" curve, when the maximum effect is produced at very low and very high concentrations, but not at intermediate levels; in the "inverted U-shaped" curve the opposite occurs. Such curves represent a huge controversy in ecotoxicology because they contradict the well-stablished linearity of dose-response relationships. Not surprisingly, most chemicals have their environmental safety levels based on this assumption, and the detection of these nonlinear relationships is an area in which behavioral studies can contribute significantly to ecotoxicology (vom Saal et al., 1995; Clotfelter et al., 2004). It is believed that underreporting of nonlinear concentrationresponse relationships, with a few number of publication representability, occurs due to its deviation from toxicological dogma (Calabrese; Baldwin, 2003).

\section{CONCLUSIONS}

Due to the obtained range of sensitivity to the reference substance and the absence of mortality during the test in any of the replicates, the suitability and sensitivity of Eisenia andrei population are assured by the alternative raise method exposed in this study, for use in avoidance tests.

The essay system was thus validated, showing the suitability of the exposure conditions.

The absence of clear avoidance response in the antimicrobian sulfadiazine essays did not allow to estimate, under test conditions, a nominal EC50-48h value for earthworms Eisenia andrei, in tropical artificial soil.

We concluded that behavioral tests can contribute as an early warning signal of environmental protection.

\section{REFERENCES}

ALDAYA, M.M.; LORS, C.; SALMON, S.; PONGE, J.F. 2006. Avoidance bio-assays may help to test the ecological significance of soil pollution. Environ. Pollut., 140: 173-180. http://dx.doi. org/10.1016/j.envpol.2005.06.011

ALWORTH, L. C.; HOWDESHELL, K. L.; RUHLEN, R. L.; DAY, J. K.; LUBAHN, D. B.; HUANG, T. H.-M.; BESCHWILLIFORD, C. L.; VOM SAAL, F. S. 2002. Uterine responsiveness to estradiol and DNA methylation are altered by fetal exposure to diethylstilbestrol and methoxychlor in CD-1 mice: effects of low versus high doses. Toxicol. Appl. Pharm, 183: 10-22. http://dx.doi.org/10.1006/taap.2002.9459

CALABRESE, E. J.; BALDWIN, L. A. 2003. Toxicology rethinks its central belief. Nature, 421: 691-692. http://dx.doi. org/10.1038/421691a

ClOTFElTER, E. D.; BELL, A. M.; LEVERING, K. R. 2004. The role of animal behaviour in the study of endocrinedisrupting chemicals. Animal Behav., 68: 665-678. http://dx.doi.org/10.1016/j.anbehav.2004.05.004

EIJSACKERS, H. 1978. Side effects of the herbicide 2,4,5-T affecting mobility and mortality of the springtail Onychiurus quadriocellatus Gisin (Collembola). Z. Angew. Entomol., 86: 349-372. http://dx.doi.org/10.1111/j.1439-0418.1978.tb01942.x

GARCÍA-GALAN, M. J.; DÍAZ-CRUZ, M. S.; BARCELÓ, D. 2009. Combining chemical analysis and ecotoxicity to determine environmental exposure and to assess risk from sulfonamides. Trend.Anal. Chem., 28(6): 804-819. http://dx.doi.org/10.1016/j. trac.2009.04.006

GARCIA, M. 2004. Effects of pesticides on soil fauna: development of ecotoxicological test methods for tropical regions. $\mathrm{PhD}$ Thesis. Hohen Landwirtschaftlichen Fakultät, Bonn, 291p.

GARCIA, M.; RÖMBKE, J.; BRITO, M. T.; SCHEFFCZYK, A. 2008. Effects of three pesticides on the avoidance behavior of earthworms in laboratory tests performed under temperate and tropical conditions. Environ. Pollut., 153(2): 450-456. http://dx.doi.org/10.1016/j.envpol.2007.08.007

HELLOU, J; CHEESEMAN, K; DESNOYERS, E; JOHNSTON, D; JOUVENELLE, M. L.; LEONARD, J.; ROBERTSON, S; WALKER, P. 2008. A non-lethal chemically based approach to investigate the quality of harbour sediments. Sci. Total Environ., 389: 178-187. http://dx.doi.org/10.1016/j.scitotenv.2007.08.010

HELLOU, J. 2011. Behavioural ecotoxicology, an "early warning" signal to assess environmental quality. Environ. Sci. Pollut. R., 18(1): 1-11. http://dx.doi.org/10.1007/s11356-010-0367-2

HUND-RINKE, K.; WIECHERING, H. 2001. Earthworm avoidance test for soil assessments: an alternative for acute and reproduction tests. J. Soils Sediments, 1: 15-20. http://dx.doi.org/10.1007/ BF02986464

HUND-RINKE, K., ACHAZI, R., RÖMBKE, J., WARNECKE, D. 2003. Avoidance test with Eisenia fetida as indicator for the habitat function of soils: results of a laboratory comparison test. J. Soils Sediments, 3: 7-12. http://dx.doi.org/10.1007/BF02989462

ISO (INTERNATIONAL ORGANIZATION FOR STANDARDIZATION). 1994. ISO 10390 - Soil quality determination of $\mathrm{pH}$, Geneva.

ISO (INTERNATIONAL ORGANIZATION FOR 
STANDARDIZATION). 2008. ISO 17512-1 - Soil quality: avoidance test for testing the quality of soils and effects of chemicals on behaviour. Part 1: Test with earthworms (Eisenia fetida and Eisenia andrei), Geneva.

MARQUES, B. 2012. Sulfonamidas. In: Porkworld, 59: 82-85pp. Campinas, Nov-Dez 2010. Available: http://www.formil.com. br/pork59_sanidade.pdf. Access in 16 jun 2017.

MONTEIRO, R.T.R.; FRIGHETTO, R.T.S. 2000. Determinação da umidade, $\mathrm{pH}$ e capacidade de retenção de água do solo. In: FRIGHETTO, R.T.S.; VALARINI, P.J. (eds), Indicadores Biológicos e Bioquímicos da Qualidade do Solo: Manual Técnico. Jaguariúna: Embrapa Meio Ambiente, pp. 37-40.

NATAL-DA-LUZ T.; RÖMBKE J.; SOUSA, J. P. 2008. Avoidance tests in site-specific risk assessment: influence of soil properties on the avoidance response of collembola and earthworms. Environ. Toxicol. Chem., 27: 1112-1117. http://dx.doi.org/10.1897/07-386.1

NUNES, M. E. T; ESPÍNDOLA, E. L. G. 2012. Sensitivity of Eisenia andrei (Annelida, Oligochaeta) to a commercial formulation of abamectin in avoidance tests with artificial substrate and natural soil under tropical conditions. Ecotoxicology, 21: 1063-1071. http://dx.doi.org/10.1007/s10646-012-0859-6

OECD (ORGANISATION FOR ECONOMIC CO-OPERATION AND DEVELOPMENT). 1984. Guidelines for the testing of chemicals $n^{\circ}$ 207: Earthworm acute toxicity test, Paris.

PRINCZ, J.; SCROGGINS, R. 2003. Toxicological comparison of different soil test options - earthworm lethality, avoidance and reproduction. Poster presentation, 13th Society of Environmental Toxicology and Chemistry (SETAC) Europe Meeting, Hamburg.

RANG, H.P.; DALE, M.M. 1991. Pharmacology, Churchill Livingstone, $2^{\text {nd }}$ editon, $955 \mathrm{p}$.

REINECKE, A.J.; MABOETA, M.S.; VERMEULEN, L.A.; REINECKE, S.A. 2002. Assessment of lead nitrate and mancozeb toxicity in earthworms using the avoidance response. B. Environ. Contam. Tox., 68(6): 779-786. http://dx.doi.org/10.1007/s00128-002-0023-8

ROBINSON, P. D. 2009. Behavioural toxicity of organic chemical contaminants in fish: application to ecological risk assessments (ERAs). Can. J. Fish. Aquat. Sci., 66: 1179-1188. http://dx.doi. org/10.1139/F09-069
SARMAH, A.K.; MEYER, M.T.; BOXALL, A.B.A. 2006. A global perspective on the use, sales, exposure pathways, occurrence, fate and effects of veterinary antibiotics (VAs) in the environmental. Chemosphere, 65: 725-759. http://dx.doi.org/10.1016/j. chemosphere.2006.03.026

SCHAEFER, M. 2001. Earthworms in crude oil contaminated soils: toxicity tests and effects on crude oil degradation. Soil Sediment Water, 8: 35-37.

SCHAEFER, M. 2003. Behavioural endpoints in earthworm ecotoxicology. J. Soils Sediments, 3(2): 79-84. http://dx.doi. org/10.1007/BF02991072

SCHMITT, H.; RÖMBKE, J. 2008. The ecotoxicological effects of pharmaceuticals (antibiotics and antiparasiticides) in the terrestrial environment - a review. In: KÜMMERER, K. (ed), Pharmaceuticals in the environment: sources, fate, effects and risks. $3^{\text {rd }}$ ed. Springer: Verlag Berlin Heidelberg, pp. 285-303. http://dx.doi.org/10.1007/978-3-540-74664-5_18

STEPHENSON, G.; KAUSHIK, A.; KAUSHIK, N.K.; SOLOMON, K.R.; STEELE, T.; SCOGGINS, R.P. 1998. Use of an avoidance-response test to assess the toxicity of contaminated soils to earthworms. In: SHEPPARD, S.; BEMBRIDGE, J.; HOLMSTRUP, M.; POSTHUMA, L. (eds), Advances in Earthworm Ecotoxicology, Pensacola: SETAC Press, pp. 67-81.

THIELE-BRUHN, S. 2003. Pharmaceutical antibiotic compounds in soils - a review. J. Plant Nutr. Soil Sci., 166: 145-167. http:// dx.doi.org/10.1002/jpln.200390023

VAN GESTEL, C.A.M. 2012. Soil ecotoxicology: state of the art and future directions. ZooKeys, 176: 275-296. http://dx.doi. org/10.3897/zookeys.176.2275

VOM SAAL, F. S.; NAGEL, S. C.; PALANZA, P.; BOECHLER, M.; PARMIGIANI, S.; WELSHONS, W. V. 1995. Estrogenic pesticides: binding relative to estradiol in MCF-7 cells and effects of exposure during fetal life on subsequent territorial behavior in male mice. Toxicol. Letters, 77: 343-350. http://dx.doi.org/10.1016/0378-4274(95)03316-5

YEARDLEY JR., R.B.; LAZORCHAK, J.M.; GAST, L.C. 1996. The potential of an earthworm avoidance test for evaluation of hazardous waste sites. Environ. Toxicol. Chem., 15 (9): 1532 1537. http://dx.doi.org/10.1002/etc.5620150915 